\title{
Implementing Test Enhanced Learning: Swedish Teacher Students' Perception of Quizzing
}

\author{
Mikaela Nyroos $^{1}$, Ingrid Schéle ${ }^{2} \&$ Carola Wiklund-Hörnqvist ${ }^{2}$ \\ ${ }^{1}$ Department of Education, Umeå University, Umeå, Sweden \\ ${ }^{2}$ Department of Psychology, Umeå University, Umeå, Sweden \\ Correspondence: Mikaela Nyroos, Department of Education, Umeå University, 90187 Umeå, Sweden. Tel: \\ 46-70-2643-051.E-mail: mikaela.nyroos@umu.se
}

Received: August 15, 2016

Accepted: August 30, 2016

Online Published: September 9, 2016

doi:10.5430/ijhe.v5n4p1

URL: http://dx.doi.org/10.5430/ijhe.v5n4p1

\begin{abstract}
Given previous findings on test enhanced learning, the present study examined the implementation of this practice in terms of quizzing, during the progress of a course. After completing the university course, 88 Swedish teacher students were asked to answer an adapted Retrieval Practice and Test Anxiety Survey. The results showed that students perceived quizzing to improve learning, and reduce test anxiety. Nonetheless, based on students' misconceptions regarding why quizzing actually enhances learning, it is suggested that implications of test enhanced learning was not fully conveyed. It is for educational purpose imperative to not forget this application.
\end{abstract}

Keywords: The testing effect, Test anxiety, Teacher education, Quizzing

\section{Introduction}

\subsection{Durable Learning}

To study is one of the most used strategy to learn, but studying per se is no guarantee for actual learning to be successfully achieved. For the intended learning to occur, the to-be-learned-information needs to be mentally processed; i.e. fundamentally, be preserved, or formed to a memory (Zovkic, Guzman-Karlsson, \& Sweatt, 2013). Simply put, as memories are formed, learning takes place. The effectiveness of learning, ultimately memory processing, is closely linked to the type of study practice the learner is subject to.

Several studies have substantiated that study activities resulting in durable learning, require students to be engaged in effortful activities (Freeman et al., 2014; Pennebaker, Gosling, \& Ferrel, 2013). One method, that has shown to be superior compared to several common learning methods and across different study materials, is test enhanced learning or repeated testing. Test enhanced learning requires the student to actively retrieve knowledge from memory when responding, and each time an item is retrieved this strengthens the memory traces (Hattikudur \& Postle, 2011). The effect following test enhanced learning is commonly referred to as the testing effect (Dunlosky, Rawson, Marsh, Nathan, \& Willingham, 2013; Karpicke, 2012). The testing effect refers to empirically demonstrable enhancement of the long-term retention of information by repeated tests (Roediger \& Karpicke, 2006).

Nonetheless, relatively few students have knowledge of or utilise test enhanced learning as a study tool (see e.g., Benassi et al., 2014; Gilmore \& Cragg, 2014; Schutte et al., 2015). This may come down to lack of knowledge about test enhanced learning as a learning event in itself. In order for students to develop effective study strategies they initially need to be informed, and schooled (see Einstein, Mullet, \& Harrison, 2012). In the present study a sample of Swedish teacher students were engaged in test enhanced learning in the form of repeated quizzing.

A key element of any education system is testing, in large part because there can be no knowledge of the outcome of the education without tests of some kind. But in the perspective of so far summing efforts, and forming future endeavours, students who take tests will most likely to some degree and at some point experience stress and worry linked to testing. Thus, for some individuals testing may be associated with high stress and worries. These worries may result in, among others things, impaired testing performance and learning, a phenomenon often referred to as test anxiety (Liew, Lench, Kao, Yeh, \& Kwok, 2014; Nelson, Lindstrom, \& Foels, 2014). On the other, implementing testing during the progress of a course, as a supplementary aid in learning (i.e., indirect effect of the testing effect) might reduce these negative emotions (Messineo, Gentile, \& Allegra, 2015). The present study also examines this 
phenomenon in the perspective of teacher students' experience of test enhanced learning.

\subsection{Testing: Pros and Cons}

Correctly applied, testing is a powerful learning tool; on the downside it may lead to high levels of stress; the crux of testing is to minimise performance anxiety, while at the same time enhancing its beneficial effects on learning. A strong candidate for such good practice is repeated quizzing, a method that may enhance learning while migitating examination stress (Hinze \& Rapp, 2014; Messineo et al., 2015).

\subsection{The Testing Effect}

Testing is not merely an encoding trial or neutral in terms of learning, as it promotes a form of processing of target material that improves retention and subsequent test performance. Hence, testing is a robust technique for both assisting students in learning, and improving their memory of the material (McDaniel, Anderson, Derbish, \& Morrisette, 2007; Roediger \& Karpicke, 2006). Test enhanced learning may therefore be a valuable pedagogical tool and enhance learning via both mediated and unmediated effects (cf. Jensen, McDaniel, Woodard, \& Kummer, 2014).

The mediated (or indirect) effects are related to for example students' motivation and attitudes towards various aspects of school, the encouragement to study more continuously and prepare for class, the shaping of their learning from feedback, information about what they have and have not learned, guidance for future study, and acquisition of 'test-wiseness' (McDaniel et al., 2007). In sharp contrast to widely expressed concern that excessive particularly high stake - testing caused stress and worry among students, test-enhanced learning appears to reduce this syndrome (Messineo et al., 2015; Szpunar, Khan, \& Schacter, 2013), and students who are accustomed to regular tests seem to develop resistance to test anxiety (see Meyer \& Logan, 2013; Nyroos, Korhonen, Linnanmäki, \& Svens-Liavåg, 2012).

The direct (unmediated) effects of testing are the enhancement of higher level thinking and memory (i.e., the testing effect). A growing body of empirical evidence shows that repeated testing is highly effective for improving the accuracy of long-term memory - frequent testing is a powerful mnemonic aid for future retention (Roediger \& Butler, 2011; Rowland, 2014). Test enhanced learning has recently been acknowledged as a learning method with the highest utility compared to other pedagogical methods. Specifically that the method produces sustainable learning (Dunlosky et al., 2013) has great potential for educational purposes. As a person takes a test and retrieves some piece of information the memory traces are strengthened. This promotes long-term recall via a process different from studying the same material repeatedly, and thus may be beneficial for both high- and low-achievers (Wiklund-Hörnqvist, 2014; Wiklund-Hörnqvist, Jonsson, \& Nyberg, 2014).

Furthermore, taking a test on a specific material can have a greater positive effect on future retention of the material compared to studying it for equivalent amount of time (e.g., Benassi et al., 2014; Hattikudur \& Postle, 2011; Pennebaker et al., 2013), even if the performance is far from perfect and no feedback is given (Roediger \& Karpicke, 2006). Repeated study may yield better results in immediate tests, while repeated testing will foster superior long-term retention, as manifested in results of tests after several days or years (McDermott, Agarwal, D'Antonio, Roediger, \& McDaniel, 2014).

Testing has also proved to be an effective and highly useful strategy to avoid mere rote learning and promote deep and meaningful understanding of the studied material (Dunlosky et al., 2013). This is at least partly because it counteracts tendencies of students to stop studying before the material is adequately learned (Miesner \& Maki, 2007), or once they have just understood it (Metcalfe, Kornell, \& Son, 2007). Testing may also counter the tendency of some students, notably those with memory problems, to use simpler but less effective tools such as rehearsal of information (Jonsson, Wiklund-Hörnqvist, Nyroos, \& Börjesson, 2014; Pennebaker et al., 2013).

There may be resistance to testing and/or low awareness of its benefits because repeated studying may be regarded as less demanding, more advantageous in the short term and thus more appealing than testing (Roediger \& Karpicke, 2006). Accordingly, Kornell and Bjork (2007) found that only $18 \%$ of 472 college students regarded testing as learning events. In keeping with this, a study by Karpicke, Butler and Roediger (2009) showed that among 177 surveyed undergraduate students, only $1 \%$ listed self-testing as the number one learning strategy, whereas $55 \%$ of the students ranked restudy the material as the number one learning strategy. Given these results it seems that students lack the knowledge of how to best regulate and monitor their own learning in order to become a sophisticated learner (Bjork, Dunlosky, \& Kornell, 2013).

The testing effect has proved to be robust across diverse types of materials (e.g., verbal, prose passages, symbols, and simple pictures), different types of tests (e.g., prose materials, free-recall, multiple-choice or short-answer, high- or low stakes tests), and disciplines and contexts (e.g., laboratory settings and classroom) as well (see Stenlund, 
Sundström, \& Jonsson, 2014; Wiklund-Hörnqvist et al., 2014). Although the testing effect has been repeatedly shown to have significant learning effects, relatively little attention has been paid both to apply it in practice and researching ways to optimise its application in naturalistic settings (Benassi et al., 2014; Karpicke \& Blunt, 2011). In Sweden, overall, little attention has been paid to the testing effect (see Stenlund et al., 2014; Wiklund-Hörnqvist et al., 2014).

\subsection{Test Anxiety}

Individuals who suffer from test anxiety feature excessive fear and problems with functioning - before, during and after taking an exam - as a result. Symptoms are distributed along a continuum and range from moderate to severe, and commonly include physiological, behavioural and cognitive responses related to a test situation (Putwain, 2008). In the short term test anxiety is generally associated with impairment of academic performance and educational achievement (Maloney, Sarrizahn, \& Beilock, 2014), while in the long term it may diminish access to educational and occupational opportunities (Kumar \& Karimi, 2010), and contribute to ill-health (Putwain, 2008).

Test anxiety is believed to interfere with memory performance by disrupting encoding and the organisation of the rehearsed material, and subsequent retrieval of the rehearsed material in test situations (DeCaro, Thomas, Albert, \& Beilock, 2011; Maloney et al., 2014). Elevated levels of test anxiety are also linked to procrastination and loss of motivation to engage in academic work (Mavilidi, Hoogerheide, \& Paas, 2014). Although levels of test anxiety depend on the social and educational functions of both the schools and tests involved (Song, Bong, Lee, \& Kim, 2015; Varela \& Hensley-Maloney, 2009), for example whether the tests are low- or high-stakes (Segool, Carlson, Goforth, von der Embse, \& Barterian, 2013), it typically weakenes educational performance, and burdens individuals regardless of the cultural setting when levels are excessive (Liew et al., 2014; Nelson et al., 2014). Nonetheless, in Sweden test anxiety has drawn little attention from the educational field (see Nyroos et al., 2015).

In summary, repeatedly administrating course based quizzing is a resource-effective instructional method that could potentially improve students' achievements in exams and reduce their exam stress substantially. Testing effects and test anxiety are potentially important educational factors to exploit and address, respectively, in both research and practice. The present study addresses the two benefits of the test enhanced learning in the settings of a regular Swedish university course.

\subsection{Swedish Education}

Two important prerequisites inform Swedish education and span through all levels of education: governance by objectives and results, and equal educational opportunities to all citizens. The adoption of a far-reaching decentralisation serves as a means to accomplish both prerequisites. The introduction, of e.g. school autonomy, increased individualisation, school vouchers, and entrepreneurships, encompass a curricula content and corresponding grading criteria exploiting metacognitive and self-regulating abilities (see Partanen, 2016), and has meant a shift in responsibility from the school to the student; as well as a shift from a fact-intermediary school to a strategy- and tool-intermediary school.

Over the years, testing has gotten a rather tarnished reputation in the Swedish school system, leading to schooling that involves few examinations by international standards (see Nyroos et al., 2015), and requires students to spend minimal hours outside class doing homework or other study set by teachers (OECD, 2014). These are also common features of Swedish teacher education, in which seminars and memos are prominent forms of assessment (Högskoleverket, 2006; SOU 2008:109), but there are generally few unit exams (Lundgren, 2001), and expected learning outcomes tap the "master-apprentice model of learning", which focuses on apprenticeship, and proven experience (Männikkö-Barbutiu, Rorrison, \& Zeng, 2011, p. 52).

Moreover, Lundgren (2001) saw that teacher students spent substantially less time studying than many of their peers tackling other disciplines (i.e., medics, civil engineers, and psychologists). Lundgren concluded that the variation in time was a manifestation of different traditions of demands and studies, as well as students' disposition towards their studies. This line of reasoning has been supported by SCB (2007), and recently by Bertilsson (2014), who concluded that in Sweden today a high proportion of teacher students are academic low-achievers who lack effective study strategies, and spend little time on studying. Equally, in an OECD (2015a) report, the declining status of teacher education, as compared to other educational programmes, was argued to have led to low admission requirements.

Sweden's teacher education is to a high degree decentralised, meaning that qualification description and goals for the teacher qualification is laid down by the Government, and all teaching training colleges autonomously decide on course content and forms to fulfil these requirements. However, recently OECD (2015a) designated this decentralised system to be responsible for poor Swedish teachers' instructions methods, as well as for Swedish 15-year-olds dramatic academic performance decline on international rankings. Instead of course contents focusing 
effective teaching and learning methods, teacher education were blamed to constitutes a platform advocating progressive education (OECD, 2015a). The consequences are apparent across ages; for example in a study by Falch and Rønning (2012) on the effects of homework, Sweden emerged as an outlier with a significant negative effect of teacher assigned homework on student achievement in mathematics and science when compared to 16 other countries (TIMMS). In the PISA 2009 report, Swedish students scored below the OECD average on several measures on effective study strategies: Swedish students were among the least knowledgeable about effective strategies in terms of: to understand and summarise information, to understand and remember information, to understand and memorise information OECD (2010). In addition, 84\% of 15-year-old students in Sweden think they perform poor on an exam irrespectively of having studied or not (OECD, 2012). In a study by the Swedish National Union of Students (2014), Swedish university students ranked instruction on learning activities - that were planned by the teacher and initiated by the student - as the most important factor to promote quality education.

Teachers are responsible for implementing, upholding and realizing centrally stipulated objectives and guidelines (Beach, Bagley, Eriksson, \& Player-Koro, 2014; Crasborn, Hennissen, Brouwer, Korthagen, \& Bergen, 2008) but the outcome inevitably depends on the organisation of studies and set education content, as appointed assignment and implementation approach (see Stone-Johnson, 2011; Swoboda, 2014). The educational quality is in some respect also depend on what learning activities teachers promote and provide to students (Freeman et al., 2014; Pennebaker, Gosling, \& Ferrel, 2013). From the vantage point of teachers, the instruction methods the teacher has been subjected to as a student, is argued to be reflected in the instructions methods later adopting as a teacher (see Morehead, Rhodes, \& DeLozier, 2015). In a sense, the foundation of teachers' knowledge on instruction and learning, is teacher education (cf. Nilsson Lindström \& Beach, 2015; Poulou, 2007).

From this perspective, to partake in activities based on advances in so-called non-traditional field, such as cognition, that could improve learning and development for teachers, and teachers' mentors, is imperative (Freeman et al., 2014). Experimental research on human learning and (especially) memory could offer concrete guidance regarding strategies to optimise teaching and enhance learning (see Engle, 2010; Freeman et al., 2014). Therefore, the present study examines the experience of a sample of Swedish teacher students subjected to a university course adopting cognitive based learning, i.e. test enhanced learning.

\subsection{Aim}

The aim of the present study is to investigate which learning strategies students commonly use and examine how students perceive the implementation of test enhanced learning during the progress of a course. More specifically, we address the following research questions:

q1: What are teacher students' main study habits?

q2: How do teacher students perceive the implementation of test enhanced learning?

\section{Method}

\subsection{Participants}

A convenience sample of 88 university students (59 women, 29 men; mean age 23, age range 18-38 years) registered 2014 on the first semester course Knowledge, Education and Learning (10.0 Credits) participated in the study. The quizzing tool was used for part of the course, Developmental Psychology (about 3.0 Credits), and was included as an additional, non-scheduled learning assignment. The quizzing proceeded for eight days and was voluntary. A unit exam took place 17 days after the introduction of quizzing.

\subsection{Materials and Procedure}

\subsubsection{Quizzing Material}

Two of the researchers taught at the course, and also administrated and introduced the quizzing as a learning tool. The quizzing material used consisted of 172 questions concerning topics covered in six chapters of the textbook "Developmental psychology for educators: an introduction" (Gruber, 2011). The questions, arranged in sections corresponding to specific chapters and related lectures, included multiple-choice and short-answer questions.

For the multiple-choice questions, a statement or problem was presented together with five response alternatives, one of which was always "I don't know". Immediately after responding the student received feedback in the form of a correct answer without the question being shown. For the short-answer questions, the students were asked to define key concepts covered in the assigned readings. Immediately after a response was typed in, the student received feedback in terms of the complete correct definition. The test was self-paced and the quizzing system was available for the students at the course website. 


\subsubsection{Survey Material}

Approximately two weeks after completing the course the aforementioned student sample filled in a survey regarding their apprehension of the repeated quizzing and associated test anxiety/stress. The survey instrument was adapted from the "Retrieval Practice and Test Anxiety Survey" (Agarwal, D’Antonio, Roediger, McDermott, \& McDaniel, 2014). The questionnaire probed student perceptions of how and why they had used the quizzing tool, how it affected their learning and test anxiety, preferences regarding ordinary study habits and study partners, and willingness to use quizzing in the future. Additional questions concerned their age, gender, and study hours prior to and during the examination week. The question response formats varied (see Appendix in Agarwal et al., 2014, for details), including YES/NO, lists with alternatives (e.g., "Please describe what other type of strategies you used"), and open-ended formats to allow students to add other alternatives and explain their thoughts and feelings (e.g., "Please describe how the quizzing encounters influenced your learning of the topic").

The phrasing and order of the questions was identical to those applied by Agarwal et al. (2014), except for two modifications. First, we asked our respondents to rank their study strategies, while Agarwal et al. (2014) asked their participants merely to list applicable alternatives. This adjustment was done partly to obtain more information on the study strategies students usually use when studying on their own (one of the objectives of our study). Second, we added the following three questions to the original survey instrument: "Did you use the quizzing tool during the progress of the course?" (Yes/No); "Did you use the quizzing tool to improve your learning while quizzing?" (Yes/No); and "Did you use the quizzing tool to get information about what you know and what you do not know?" (Yes/No). The last question was included because it concerns a metacognitive aspect and prior research suggests that students commonly use quizzes to diagnose their learning (Kornell \& Son, 2009) and subsequently guide their future studies.

The survey instrument was translated from English to Swedish in two steps. First, the researchers translated the survey to Swedish, then a Swedish citizen with English as native language back-translated the survey to English. No further changes were needed based on this procedure.

\section{Results and Discussion}

\subsection{Time Spent Studying}

On average the full-time students spent less than eight hours per week (Table 1) outside classes studying Developmental Psychology, and intensified their effort during the week of the unit exam by $45 \%$, to appr. 11.5 hours studying. More than a third of the teacher students reported that they spent more time studying for the focal course than for other courses $(35 \%)$ (Table 1$)$.

Table 1 . Numbers of hours spent by students outside of class

\begin{tabular}{lc|lc}
\hline $\begin{array}{l}\text { Study hours spent on a weekly } \\
\text { basis }\end{array}$ & $\begin{array}{c}\text { Swedish } \\
\text { sample (h) }\end{array}$ & $\begin{array}{l}\text { Study time spent } \\
\text { relative to other } \\
\text { classes }\end{array}$ & $\begin{array}{c}\text { Swedish } \\
\text { sample } \\
(\%)\end{array}$ \\
\hline $\begin{array}{l}\text { In weeks with no upcoming } \\
\text { exam }\end{array}$ & 7.89 & More & 35 \\
In weeks with upcoming exam & 11.47 & $\begin{array}{l}\text { Less } \\
\text { The same amount }\end{array}$ & 12 \\
\hline
\end{tabular}

These results are consistent with official and common media views, and recent research findings (e.g., Bertilsson, 2014), that teacher students in Sweden invest little effort in their studies. Moreover, their invested efforts seem to have been quite stable over time, as Lundgren (2001) found that $80 \%, 55 \%$ and $25 \%$ of teacher students, at the university we studied spent less than 15, 10 and 20 hours weekly on study outside scheduled activities, scheduled teacher-governed activities, and all study-related activities, respectively.

In addition, the Swedish education system, including teacher education, is characterised as a low stakes system (see Nyroos et al., 2015). Thus, the Swedish techer students may have been less motivated to study.

\subsection{Indirect Effects of the Retrieval Practice}

Slightly more than half (52\%) of the responding teacher students reported that the retrieval practice, i.e. using the quizzing tool, made them less anxious about the unit exam (Table 2). Approximately equal proportions of the responding teacher students self-reportedly experienced more, less and similar test anxiety for the unit exam in the 
focal Developmental Psychology course compared to other courses in the teacher program (Table 2).

Table 2. Percent of students who self-reported on the effect of quizzes on experienced test anxiety about the unit exam; and percent of students who self-reported on experienced test anxiety before the unit exam of the focal course, relative to other classes

\begin{tabular}{lc|lc}
\hline $\begin{array}{l}\text { Experienced test anxiety } \\
\text { before unit exam, relative } \\
\text { to quizzing }\end{array}$ & $\begin{array}{c}\text { Swedish } \\
\text { sample } \\
(\%)\end{array}$ & $\begin{array}{l}\text { Experienced test anxiety } \\
\text { before unit exam, relative to } \\
\text { other classes }\end{array}$ & $\begin{array}{c}\text { Swedish } \\
\text { sample } \\
(\%)\end{array}$ \\
\hline More & 7 & More & 33 \\
Less & 52 & Less & 29 \\
About the same & 41 & About the same & 39 \\
\hline
\end{tabular}

The perceived lessening in exam anxiety by quizzing is consistent with previous findings (e.g., Agarwal et al., 2014; Szpunar et al., 2013). However, the students in the Swedish sample did not report any difference in perceived test anxiety compared to other courses. Only $24 \%$ of the teacher students in our sample included reduced test anxiety among the top-four benefits of quizzing (see Table 4 for more details). The present sample was engaged in test enhanced learning for a fairly short period of time (cf. Roediger \& Karpicke, 2006), and thus, indicate that quizzing has considerable scope for further reducing levels of test anxiety among teacher students in Sweden. On the other hand, test anxiety appears to be a learnt phenomenon (Bandura, 1982). That tests, in the Swedish goal-oriented education system, is one adjacent method in summing and assessing learners' achievements not used to compare students, that no formal final examinations exist, that tests results are not linked to accountability, and that Swedish teachers may curry favour with testing among students (e.g., play down stakes see Nusche, Halász, Looney, Santiago, \& Shewbridge, 2011), test anxiety could be argued to be a fairly unrecognised educational issue in the present context.

Table 3. Percent of students listing different negative responses to quizzing; and percent who listed negative responses as their top four (\#1-4) responses

\begin{tabular}{lc|lc}
\hline $\begin{array}{l}\text { Listed negative } \\
\text { response }\end{array}$ & $\begin{array}{c}\text { Swedish } \\
\text { sample (\%) }\end{array}$ & $\begin{array}{l}\text { Listed \#1-4 negative } \\
\text { responses }\end{array}$ & $\begin{array}{c}\text { Swedish } \\
\text { sample (\%) }\end{array}$ \\
\hline 1. Made me nervous & 10 & 1. Boring & 22 \\
2. Boring & 9 & 2. Made me nervous & 20 \\
3. Went to quickly & 7 & 3. Went to quickly & 15 \\
4. Liked nothing about it & 2 & 4. Liked nothing about it & 14 \\
\hline
\end{tabular}

It is promising that very few of the responding students $(<5 \%)$ explicitly stated that they did not like quizzing at all (Table 3). The top negative responses were "Made me nervous" (10\%) and "It was boring" (9\%). Furthermore, only one out of five teacher students (22\%) listed "Boring" in their top four reasons for not liking quizzing, while almost half of the U.S. sample (47\%) cited the same response, indicating that further investigation about the possible optimal duration of quizzing related to different outcomes is warranted. Or that encouraging the use of quizzing, as well as informing about the benefits and potential of quizzing in studying and learning, is required; especially considering only $14 \%$ (Table 4) of the Swedish teacher students linked "Means of assessing" to quizzing and learning (see discussion below).

\subsection{Direct Effects of the Retrieval Practice}

Almost all the respondents used quizzing (96\%), and almost all respondents who used it (97\%) reportedly used it to enhance their learning and/or to obtain feedback (93\%). Indeed, in line with previous findings (e.g., Roediger \& Karpicke, 2006), the large majority of the responding teacher students $(90 \%)$, reported that the retrieval practice improved their learning.

The most common reasons stated for why teacher students believed quizzes improved learning were that it assisted "Test preparation [for the unit exam]" (32\%), "Reviewing/summarising" (18\%), and "Means of assessing" (14\%), see Table 4. "Test preparation" (63\%) was also the most frequently cited reason in the lumped responses, followed by "Reviewing/summarising" (57\%), and "Providing feedback" (52\%) as shown in Table 4. 
Table 4. Percent of students listing different reasons for learning; and percent who listed reasons as their top four (\#1-4) reasons

\begin{tabular}{lc|lc}
\hline Listed reason & $\begin{array}{c}\text { Swedish } \\
\text { sample (\%) }\end{array}$ & Listed \#1-4 reasons & $\begin{array}{c}\text { Swedish } \\
\text { sample (\%) }\end{array}$ \\
\hline 1. Test preparation & 32 & 1. Test preparation & 63 \\
2. Review/summarise & 18 & 2. Review/summarise & 57 \\
3. Means of assessing & 14 & 3. Provided feedback & 52 \\
4. Provided feedback & 11 & 4. Metacognition & 42 \\
5. Helped me focus & 6 & 5. Helped me focus & 32 \\
6. Reduced anxiety & 3 & 6. Reduced anxiety & 24 \\
7. Fun & 2 & 7. Fun & 20 \\
\hline
\end{tabular}

Test enhanced learning, per definition, is supposed to enhance learning, implying an effective use of study time and therefore not at the cost of time; Agarwal and colleagues (2014) suggested that if students did not study more time for classes associated with quizzing, it could be interpreted as retrieval practice was implemented. In the present study, $35 \%$ of the teacher students reported that they studied more for the class where quizzing was introduced (Table 1). In keeping with this, several other researchers (e.g., Bjork et al., 2013; Kornell \& Son, 2009; Tullis et al., 2013) have argued that many learners only recognise the indirect effects of test enhanced learning (i.e., means of assessing, or diagnostic tool) but not the direct (mnemonic) effects it has on improving memory retention. Such misconceptions about learning through retrieval practices is discernible in Table 4, where more than half (63\%, 57\%, and 52\%), and $42 \%$ judged those second benefits as top four reasons pursuing learning. In addition, only half (55\%, 50\%) or less than half of the present sample $(30 \%, 24 \%$, and 14\%) listed using study strategies (Table 5, and see the section below) that are related to a cognitive effect, i.e. the mere act of testing strengthens the memory (e.g., Wiklund-Hörnqvist et al., 2014). Once again we see the need to include teaching on the benefits of test enhanced learning to the students introduced to, using, and hopefully in turn implement the method on disciples of their own in order to help them understand and maximize said benefits.

\subsection{Study Strategy Preferences}

Study habits mentioned by the students (Table 5) included "Reviewing/summarising" (30\%), "Repeating facts" (25\%), "Self-testing" (24\%), "Testing by someone" (17\%), and "Remembering facts via quizzes" (15\%).

Table 5. Percent of students listing preferred study strategy; and percent who listed strategies as their top four (\#1-4) strategies

\begin{tabular}{lc|lc}
\hline Listed strategy & $\begin{array}{c}\text { Swedish } \\
\text { sample (\%) }\end{array}$ & Listed \#1-4 strategies & $\begin{array}{c}\text { Swedish } \\
\text { sample (\%) }\end{array}$ \\
\hline 1. Review materials & 30 & 1. Review materials & 72 \\
2. Repeat facts & 25 & 2. Repeat facts & 70 \\
3. Self-test & 24 & 3. Tested by someone else & 55 \\
4. Tested by someone else & 17 & 4. Think of quizzes & 50 \\
5. Think of quizzes & 15 & 5. Self-test & 30 \\
6. Flashcards & 8 & 6. Flashcards & 24 \\
7. Mnemonics & 5 & 7. Mnemonics & 14 \\
8. Other & 2 & 8. Other & 9 \\
\hline
\end{tabular}

With regards to studying alone or with partners "Studying alone" was preferred by the highest proportions of all teacher students (49\%). Overall, the next most common responses were "Studying with a group" (26\%) and "With a friend" (21\%), as shown in Table 6. 
Table 6. Percent of students listing with whom to normally study for a test; and percent who listed study partners as their top four (\#1-4) study partners

\begin{tabular}{lc|lc}
\hline Listed study partner & $\begin{array}{c}\text { Swedish } \\
\text { sample (\%) }\end{array}$ & $\begin{array}{l}\text { Listed \#1-4 study } \\
\text { partners }\end{array}$ & $\begin{array}{c}\text { Swedish } \\
\text { sample (\%) }\end{array}$ \\
\hline 1. Alone & 49 & 1. Alone & 94 \\
2. Study group & 26 & 2. With a friend & 85 \\
3. With a friend & 21 & 3. Study group & 81 \\
4. Other & 3 & 4. Parents or guardian & 39 \\
5. Parents or guardian & 0 & 5. Other & 11 \\
\hline
\end{tabular}

A study on study strategies by Hartwig and Dunlosky (2012) revealed that more than twice as many (71\%) of students, enrolled in introductory psychology courses, used self-testing on a regular basis; almost as many (66\%) reviewed materials, more than twice as many (62\%) used flashcards, while $50 \%$ of those students studied with friends (note that in this study no study strategies were afforded). Moreover, Hartwig and Dunlosky (2012) found a positive relationship between spontaneously used self-testing and academic outcome, and a negative relationship between collaborative studying and academic outcome. Thus, although the present sample of teacher students reported several reasons for quizzing to aid their learning (Table 4), and not really objected to quizzing per se (Table 3 ), when it comes down to it, they seem to give in to less useful learning strategies; while "Self-test", "Tested by someone else", and "Think of quizzes", still only attract less than one fourth ( $24 \%$, see Table 5$)$.

The typical study habits of the present sample (Table 5), and presumably few study hours in general (see Table 1), corroborate a cumulative picture of Swedish learners' sub-optimal learning activities (e.g., Bertilsson, 2014), and common (mis)comprehension of the foundation for learning (e.g., Männikkö-Barbutiu et al., 2011).

\section{Conclusion}

There is a growing body of evidence indicating that test enhanced learning may be a largely untapped resource for improving students' long-term retention performance in educational settings (see McDermott, Arnold, \& Nelson, 2014). Teacher education may serve to offset this limitation and provide future teachers with the skills they need to teach effectively.

The aim of the present study was to examine students' perception of the implementation of test enhanced learning during the progress of a teacher education course. Overall the students perceived quizzing to increase learning and decrease test anxiety. However, uncertainties remain whether the primary mnemonic benefits of using retrieval practice was immediate accomplished. Based on the students' misconceptions why quizzing actually enhances learning (i.e., not grasping the direct effects), and their general unawareness of study strategies that produces powerful benefits for memory, the testing effect, was likely not fully implemented in the present study.

Indeed, one of the distinct strengths of test enhanced learning, is that it promotes study strategic competencies in students that "potentiate subsequent learning" (Arnold \& McDermott, 2013, p. 1). Yet, in addition to helping student to learn - via improved study effectiveness - the primary benefits of the testing effects is improved retention and long-term memory (e.g., Roediger \& Karpicke, 2006). Therefore, in terms of these mnemonic benefits of testing, several researchers (e.g., Agarwal et al., 2014; Kornell \& Bjork, 2007) have postulated that non-compliance with memory enhancement implicates that the testing effect is not properly realised. This implementation issue is not unique to the present study but aligns with other findings (e.g., Bjork et al., 2013; Tullis et al., 2013). Because test enhanced learning has two focal effects: greater retention of the retrieved material (the direct effects), and the potential to improve study strategies (the indirect effects), it is for educational purpose imperative to not forget the full application. An improved theoretical understanding of the direct mnemonic effects involved in the testing effect provides the starting point from which to help students develop their awareness of the practical significance. To make teachers (students) increasingly aware of the testing effect, any efforts to translate the extant knowledge base on the testing effects into meaningful educational experiences, thus hinges on practices as to knowledge on what the testing effect means and what it entails.

Official reports, media, and research indicate that there are major deficiencies in Swedish schooling (e.g., low international rankings in knowledge, attitude, and motivation: OECD, 2014, 2015b). Various critics hold the Swedish teacher education programs at least partly responsible for these deficiencies (e.g., Beach et al., 2014), because of adherence to traditional, counter-productive practices and neglect of certain study strategies tapping cognition and 
associated with academic achievements. Teachers tend to take on the instruction methods they have been exposed to and have experiences of (see Morehead et al., 2015). Clearly, fostering and raising awareness in teacher students, of effective learning methods and how learning is accomplished, could pave the path for their pupils to become lifelong learners (see Swoboda, 2014). Thus, in the case of Swedish (teacher) education, instructional theories merit considerable more attention in the future.

Despite the limitations of the present study (notably our use of a small convenience sample, no control group, one-item measure), the results indicate interesting findings in line with previous research (e.g., Agarwal et al., 2014). The teacher students' positive responses to repeated quizzing are particularly promising, as test-enhanced learning could shape the attitudes of budding teachers (Morehead et al., 2015). They in turn will be responsible for implementing new educational strategies - hopefully exploring and take advantage of the relationships among testing, cognitive development, emotional engagement, academic achievement and levelled anxiety.

\section{References}

Agarwal, P. K., D’Antonio, L., Roediger III, H. L., McDermott, K. B., \& McDaniel, M. A. (2014). Classroom-based programs of retrieval practice reduce middle school and high school students' test anxiety. Journal of Applied Research in Memory and Cognition, 3, 131-139. http://dx.doi.org/10.1016/j.jarmac.2014.07.002

Arnold, K. M., \& McDermott, K. B. (2013). Test-potentiated learning: Distinguishing between direct and indirect effects of tests. Journal of Experimental Psychology: Learning, Memory, and Cognition, 39(3), 940-945. http://dx.doi.10.1037/a0029199

Bandura, A. (1982). Self-efficacy mechanism in human agency. American Psychologist, 37, 122-147.

Beach, D., Bagley, C., Eriksson, A., \& Player-Koro, C. (2014). Changing teacher education in Sweden: Using meta-ethnographic analysis to understand and describe policy making and educational changes. Teaching and Teacher Education, 44, 160-167. http://dx.doi.org/10.1016/j.tate.2014.08.011

Benassi, V. A., Tappin, E. M., Overson, C. E., Lee, M. J., O’Brien, E. J., Prudhomme White, ... Hakala, C. M. (2014). Applying the science of learning: The cognition toolbox. In V. A. Benassi, C. E. Overson, \& C. M. Hakala (Eds.), Applying science of learning in education: Infusing psychological science into the curriculum (pp. 194-205). American Psychology Association.

Bertilsson, E. (2014). Skollärare: Rekrytering till utbildning och yrke 1977-2009. Doctoral thesis. Acta Universitatis Upsaliensis, Sweden

Bjork, R. A., Dunlosky, J., \& Kornell, N. (2013). Self-regulated learning: Beliefs, techniques, and illusions. The Annual Review of Psychology, 64, 417-444. http://dx.doi.10.1146/annurev-psych-113011-143823

Crasborn, F., Hennissen, P., Brouwer, N., Korthagen, F., \& Bergen, T. (2008). Promoting versatility in mentor teachers' use of supervisory skills. Teaching and Teacher Education, 24, 499-514. http://dx.doi.10.1016/j.tate.2007.05.001

DeCaro, M. S., Thomas, R. D., Albert, N. B., \& Beilock, S. L. (2011). Choking under pressure: Multiple routes to skill failure. Journal of Experimental Psychology: General, 140(3), 390-406. http://dx.doi.10.1037/a0023466

Dunlosky, J., Rawson, K. A., Marsh, E. J., Nathan, M. J., \& Willingham, D. T. (2013). Improving students' learning with effective learning techniques: Promising directions from cognitive and educational psychology. Psychological Science in the Public Interest, 14(1), 4-58. http://dx.doi.10.1177/1529100612453266

Einstein, G. O., Mullet, H. G., \& Harrison, T. L. (2012). The testing effect: Illustrating a fundamental concept and changing study strategies. Methods and Techniques, 39(3), 190-193. http://dx.doi.10.1177/0098628312450432

Engle, R. W. (2010). Role of working-memory capacity in cognition control. Current Anthropology, 51(S1), S17-S22. http://dx.doi.10.1086/650572

Falch, T., \& Rønning, M. (2012). Homework assignment and student achievement in OECD countries, no 711. Statistics Norway.

Freeman, S., Eddy, S. L., McDonough, M., Smith, M. K., Okoroafor, N., Jordt, H., \& Wenderoth, M. P. (2014). Active learning increases student performance in science, engineering, and mathematics. Proceedings of the National Academy of Sciences, 111, 8410-8415. http://dx.doi.10.1073/pnas.1319030111

Gilmore, C., \& Cragg, L. (2014). Teachers' understanding of the role of executive functions in mathematics learning. Mind, Brain, and Education, 8(3), 132-136. http://dx.doi.10.1111/mbe.12050 
Gruber, M. (2011). Developmental psychology for educators: An introduction. McGraw Hill Custom Publishing.

Hartwig, M. K., \& Dunlosky, J. (2012). Study strategies of college students: Are self-testing and scheduling related to achievement? Psychonomic Bulletin \& Review, 19, 126-134. http://dx.doi.org/10.3758/s13423-011-0181-y

Hattikudur, S., \& Postle, B. R. (2011). Effects of test-enhanced learning in a cognitive psychology course. Journal of Behavioral and Neuroscience Research, 9(2), 151-157.

Hinze, S. R., \& Rapp, D. N. (2014). Retrieval (sometimes) learning: Performance pressure reduces the benefits of retrieval practice. Applied Cognitive Psychology, 28, 5897-606. http://dx.doi.10.1002/acp.3032

Högskoleverket (2006). Examination med kvalitet: En undersökning av examinationsförfarandet vid några svenska högskolor. Swedish National Agency for Higher Education.

Jensen, J. L., McDaniel, M. A., Woodard, S. M., \& Kummer, T. A. (2014). Teaching to the test... or testing to teach: Exams requiring higher order thinking skills encourage greater conceptual understanding. Educational Psychology Review, 26, 307-329. http://dx.doi.10.1007/s10648

Jonsson, B., Wiklund-Hörnkvist, C., Nyroos, M., \& Börjesson, A. (2014). Self-reported memory strategies and their relationship to immediate- and delayed text recall and working memory capacity. Education Inquiry, 5(3), 385-404. http://dx.doi.org/10.3402/edui.v5.22850

Karpicke, J. D. (2012). Retrieval-based learning: Active retrieval promotes meaningful learning. Current Directions in Psychological Science, 21(3), 157-163. http://dx.doi.10.1177/0963721412443552

Karpicke, J. D., \& Blunt, J. R. (2011). Retrieval practice produces more learning than elaborative studying with concept mapping. Science Express, 331, 772-775. http://dx.doi.org/10.1126/science.1199327

Karpicke, J. D., Butler, A. C., \& Roediger, H. L. (2009). Metacognitive strategies in student learning: Do students practice retrieval when study on their own? Memory, 17, 471-479. http://dx.doi.org/10.1080/09658210802647009

Kornell, N., \& Bjork, R. A. (2007). The promise and perils of self-regulated study. Psychonomic Bulletin and Review, 14(2), 219-224. http://dx.doi.org/10.3758/BF03194055

Kornell, N., \& Son, L. K. (2009). Learners' choices and beliefs about self-testing. Memory, 17, 493-501. http://dx.doi.10.1080/09658210902832915

Kumar, V., \& Karimi, A. (2010). Mathematics anxiety, mathematics performance and overall academic performance in high school students. Journal of the India Academy of Applied Psychology, 36(1), 147-150.

Liew, J., Lench, H. C., Kao, G., Yeh, Y-C., \& Kwok, O. (2014). Avoidance temperament and social evaluative threat in college students' math performance: A mediation model of math and test anxiety. Anxiety, Stress, and Coping, 27(6), 650-661. http://dx.doi.10.1080/10615806.2014.910303

Lundgren, U. P. (2001). Tid för studier. En jämförelse mellan fyra yrkesutbildningar. Swedish National Agency for Higher Education.

Maloney, E. A., Sattizahn, J. R., \& Beilock, S. L. (2014). Anxiety and cognition. WIREs Cognitive Science, 5, 403-411. http://dx.doi.10.1002/wcs.1299

Mavilidi, M-F., Hoogerheide, V., \& Paas, F. (2014). A quick and easy strategy to reduce test anxiety and enhance test performance. Applied Cognitive Psychology, 28, 720-726. http://dx.doi.10.1002/acp.3058

McDaniel, M. A., Anderson, J. L., Derbish, M. H., \& Morrisette, N. (2007). Testing the testing effect in classroom. European Journal of Cognitive Psychology, 19(4/5), 494-513. http://dx.doi.org/10.1080/09541440701326154

McDermott, K. B., Agarwal, P. K., D’Antonio, L., Roedgier, H. L., \& McDaniel, M. (2014). Both multiple-choice and short-answer quizzes enhance later exam performance in middle and high school classes. Journal of Experimental Psychology: Applied, 20, 3-21. http://dx.doi.org/10.1037/xap0000004

McDermott, K. B., Arnold, K. M., \& Nelson, S. M. (2014). The testing effect. In T. J. Perfect, \& D. S. Lindsay (Eds.), The SAGE Handbook of Applied Memory (pp. 183-200). Los Angeles: SAGE.

Messineo, L., Gentile, M., \& Allegra, M. (2015). Test-enhanced learning: Analysis of an experience with undergraduate nursing students. MBC Medical Education, 15(182), 1-7. http://dx.doi.10.1186/s12909-015-0464-5

Metcalfe, J., Kornell, N., \& Son, L. K. (2007). A cognitive-science based programme to enhance study efficacy in a 
high and low risk setting. European Journal of Cognitive Psychology, 19(4/5), 743-768. http://dx.doi.10.1080/09541440701326063

Meyer, A. N. D., \& Logan, J. M. (2013). Taking the testing effect beyond the college freshman: Benefits for lifelong learning. Psychology and Aging, 28(1), 142-147. http://dx.doi.10.1037/a0030890

Miesner, M. T., \& Maki, R. H. (2007). The role of test anxiety and relative meta comprehension accuracy. European Journal of Cognitive Psychology, 19(4/5), 650-670. http://dx.doi.10.1080/09541440701326196

Morehead, K., Rhodes, M. G., \& DeLozier, S. (2015). Instructor and student knowledge of study strategies. Memory, http://dx.doi.org/10.1080/09658211.2014.1001992

Männikkö-Barbutiu, S., Rorrison, D., Zeng, L. (2011). Memorable encounters: Learning narratives from preservice teachers' practicum. In M. Mattsson, T. Eilertsen, \& D. Rorrison, (Eds.), A Practicum Turn in Teacher Education (pp. 45-68). Boston: Sense publishers.

Nelson, J. M., Lindstrom, W., \& Foels, P. A. (2014). Test anxiety and college students with attention deficit hyperactivity disorder. Journal of Psychoeducational Assessment, 32(6), 548-557. http://dx.doi.10.1177/0734282914521978

Nilsson Lindström, M., \& Beach, D. (2015). Changes in teacher education in Sweden in the neo-liberal education age: Toward an occupation in itself or a profession for itself? Education Inquiry, 6(3), 241-258. http://dx.doi.org/10.3402/edui.v6.27020

Nyroos, M., Korhonen, J., Linnanmäki, K., \& Svens-Liavåg, C. (2012). A cross-national comparison in Swedish and Finnish grade 3 pupils: measured by the CTAS. Education Inquiry, 3(4), 615-636.

Nyroos, M., Korhonen, J., Peng, A., Linnanmäki, K., Svens-Liavåg, C., Bagger, A., \& Sjöberg, G. (2015b). Cultural and gender differences in experiences and expression of test anxiety among Chinese, Finnish and Swedish grade 3 pupils. International Journal of School and Educational Psychology, 3(1), 37-48. http://dx.doi.org/10.1080/21683603.2014.915773

OECD (2014). Education at a glance 2014 OECD indicators. OECD Publishing.

OECD (2015b). Gender equality in education. OECD Publishing.

OECD (2015a). Improving schools in Sweden: An OECD perspective. OECD Publishing.

OECD (2010). PISA 2009 Results Learning to Learn: Student engagement, strategies and practices (Volume III). OECD Publishing.

OECD (2012). PISA 2012 Results Ready to Learn: Students' engagement, drive and self-beliefs (Volume III). OECD Publishing.

Nusche, D., Halász, G., Looney, G., Santiago, P., \& Shewbridge, C. (2011). OECD reviews of evaluation and assessment in education: Sweden. OECD Publishing.

Partanen, P. (2016). Assessment and Remediation for Children with Special Educational Needs: The role of working memory, complex executive function and metacognitive strategy training. Doctoral Thesis in Psychology, Östersund: Mid Sweden University.

Pennebaker, J. W., Gosling, S. D., \& Ferell, J. D. (2013). Daily online testing in large classes: Boosting college performance while reducing achievement gaps, PLOS one, 8(11), e79774. http://dx.doi.10.1371/journal.pone.0079774

Poulou, M. (2007). Personal teaching efficacy and its sources: Student teachers' perceptions. Educational Psychology, 27(2), 191-218. http://dx.doi.org/10.1080/01443410601066693

Putwain, D. (2008). Examination stress and test anxiety. The Psychologist, 21(12), 1026-1029.

Roediger, H. L., \& Butler, A. C. (2011). The critical role of retrieval practice in long-term retention. Trends in Cognitive Sciences, 15, 20-27. http://dx.doi.10.1016/j.tics.2010.09.003

Roediger, H. L., \& Karpicke, J. D. (2006). The power of testing memory: Basic research and implications for educational practice. Perspective on Psychological Science, 1(3), 181-210. http://dx.doi.org/10.1111/j.1745-6916.2006.00012.x

Rowland, C. A. (2014). The effect of testing versus restudy on retention: a meta-analytic review of the testing effect. Psychological Bulletin, 140, 1432-1463. http://dx.doi.10.1037/a0037559 
SCB (2007). Högskolestuderandes levnadsvillkor. Statistics Sweden

Schutte, G. M., Duhon, G. J., Solomon, B. G., Poncy, B. C., Moore, K., \& Story, B (2015). A comparative analysis of massed vs. distributed practice on basic math fact fluency growth rates. Journal of School Psychology, 53, 149-159. http://dx.doi.10.1016/j.jsp.2014.12.003

Segool, N. K., Carlson, J. S., Goforth, A. N., von der Embse, N., \& Barterian, J. A. (2013). Heightened test anxiety among young children: Elementary school students' anxious responses to high-stakes testing. Psychology in the Schools, 50(5), 489-499. http://dx.doi.10.1002/pits.21689

Song, J., Bong, M., Lee, K., \& Kim, S-i. (2015). Longitudinal investigation into the role of perceived social support in adolescents' academic motivation and achievement. Journal of Educational Psychology, 107(3), 821-841. http://dx.doi.org/10.1037/edu0000016

Stenlund, T., Sundström, A., \& Jonsson, B. (2014). Effects of repeated testing on short- and long-term memory performance across different test formats Educational Psychology, 1-18. http://doi.org/10.1080/01443410.2014.953037

Stone-Johnson, C. (2011). Talkin' bout my generation: Boomers, Xers, and educational change. Journal of Educational Change, 12, 221-239. http://dx.doi.10.1007/s10833-011-9160-3

SOU (2008:109). En hållbar lärarutbildning. Stockholm: Ministry of Education and Research.

Swoboda, D. (2014). Applying evidence-based principles of learning to teaching practice: The bridging gap seminar. In V. A. Benassi, C. E. Overson, \& C. M. Hakala (Eds.), Applying science of learning in education: Infusing psychological science into the curriculum (pp. 206-214). American Psychology Association.

Szpunar, K. K., Khan, N. Y., \& Schacter, D. L. (2013). Interpolated memory tests reduce mind wandering and improve learning of online lectures. Proceedings of the National Academy of Sciences of the United States of America, 110(16), 6313-6317. http://dx.doi.10.1073/pnas.1221764110

The Swedish National Union of Students (SFS) (2014). Improving teaching and learning in Swedish higher education: A student centred perspective. Stockholm, Globalt företagstryckeri.

Trumbo, M. C., Leiting, K. A., McDaniel, M. A., Hodge, G. K. (2016). Effects of reinforcement on test-enhanced learning in a large, diverse introductory college psychology course. Journal of Experimental Psychology: Applied, 22(2), 148-160. http://dx.doi.org/10.1037/xap0000082

Tullis, J. G., Finley, J. R., \& Benjamin, A. S. (2013). Metacognition of the testing effect: Guiding learners to predict the benefits of retrieval. Memory and Cognition, 41(3), 429-442. http://dx.doi.10.3758/s13421-012-0274-5

Varela, E. R., \& Hensley-Maloney, L. (2009). The influence of culture on anxiety in Latino youth: A review. Clinical Child and Family Psychology Review, 12, 217-233. http://dx.doi.10.1007/s10567-009-0044-5

Weems, C.F., Scott, S. B., Graham, R. A., Banks, D. M., Russell, J. D., Taylor, L. K., .. Marino, R. C. (2014). Fitting anxious emotion-focused intervention into the ecology of schools: Results from a test anxiety program evaluation. Prevention Science, 16(2), 200-210. http://dx.doi.10.1007/s11121

Wiklund-Hörnqvist, C. (2014). Brain-based Teaching: Behavioral and neuro-cognitive evidence for the power of test-enhanced learning. Doctoral thesis in Psychology, Umea University, Sweden.

Wiklund-Hörnqvist, C., Jonsson, B., \& Nyberg, L. (2014). Strengthening concept learning by repeated testing. Scandinavian Journal of Psychology: Cognition and Neurosciences, 55, 10-16. http://dx.doi.10.1111/sjop.12093

Zovkic, I. B., Guzman-Karlsson, M. C., \& Sweatt, J. D. (2013). Epigenetic regulation of memory formation and maintenance. Learning \& Memory, 20, 61-74. http://dx.doi.10.1101/lm.026575.112 